\title{
An assessment of need for mental health rehabilitation amongst in- patients in a Welsh region
}

Ryan, Tony; Carden, John; Higgo, Robert; Poole, Robert; Robinson, Catherine

\section{Social Psychiatry and Psychiatric Epidemiology}

\author{
DOI: \\ $10.1007 / \mathrm{s} 00127-016-1213-8$
}

Published: 01/09/2016

Peer reviewed version

Cyswllt i'r cyhoeddiad / Link to publication

Dyfyniad o'r fersiwn a gyhoeddwyd / Citation for published version (APA):

Ryan, T., Carden, J., Higgo, R., Poole, R., \& Robinson, C. (2016). An assessment of need for mental health rehabilitation amongst in-patients in a Welsh region. Social Psychiatry and Psychiatric Epidemiology, 51(9), 1285-1291. https://doi.org/10.1007/s00127-016-1213-8

\footnotetext{
Hawliau Cyffredinol / General rights

Copyright and moral rights for the publications made accessible in the public portal are retained by the authors and/or other copyright owners and it is a condition of accessing publications that users recognise and abide by the legal requirements associated with these rights. study or research.

download and print one copy of any publication from the public portal for the purpose of private

- You may not further distribute the material or use it for any profit-making activity or commercial gain

- You may freely distribute the URL identifying the publication in the public portal?

Take down policy

The final publication is available at Springer via http://link.springer.com/article/10.1007\%2Fs00127-016-1213-8

Take down policy

If you believe that this document breaches copyright please contact us providing details, and we will remove access to the work immediately and investigate your claim.
} 


\section{Social Psychiatry and Psychiatric Epidemiology \\ An assessment of need for mental health rehabilitation amongst in-patients in a Welsh region \\ --Manuscript Draft--}

\begin{tabular}{|c|c|}
\hline Manuscript Number: & SPPE-D-15-00395R1 \\
\hline Full Title: & $\begin{array}{l}\text { An assessment of need for mental health rehabilitation amongst in-patients in a Welsh } \\
\text { region }\end{array}$ \\
\hline Article Type: & Original Paper \\
\hline Keywords: & $\begin{array}{l}\text { Rehabilitation; needs assessment; service redesign; commissioning; out of area } \\
\text { treatments }\end{array}$ \\
\hline Corresponding Author: & $\begin{array}{l}\text { Dr Tony Ryan, PhD } \\
\text { Tony Ryan Associates and Centre for Mental Health and Society, Bangor University } \\
\text { Manchester, Greater Manchester UNITED KINGDOM }\end{array}$ \\
\hline \multicolumn{2}{|l|}{$\begin{array}{l}\text { Corresponding Author Secondary } \\
\text { Information: }\end{array}$} \\
\hline Corresponding Author's Institution: & Tony Ryan Associates and Centre for Mental Health and Society, Bangor University \\
\hline First Author: & Dr Tony Ryan, PhD \\
\hline \multirow[t]{5}{*}{ Order of Authors: } & Dr Tony Ryan, PhD \\
\hline & John Carden, MSc \\
\hline & Robert Higgo, FRCPsych \\
\hline & Rob Poole, FRCPsych \\
\hline & Catherine Robinson, PhD \\
\hline \multicolumn{2}{|l|}{ Funding Information: } \\
\hline Abstract: & $\begin{array}{l}\text { Title } \\
\text { An assessment of need for mental health rehabilitation amongst in-patients in a Welsh } \\
\text { region } \\
\text { Background } \\
\text { Rehabilitation services have received little attention compared with other types of } \\
\text { mental health service provision over the past } 15 \text { years. However, they are an important } \\
\text { component of whole-system functioning in mental health services. Lack of provision } \\
\text { has a particular impact on acute in-patient services. Poor pathway management can } \\
\text { result in delayed discharges, placement of service users far from home, and resultant } \\
\text { loss of resource for the local mental health economy. } \\
\text { Methods } \\
\text { A cross-sectional study gathered demographic, clinical, service utilisation, and financial } \\
\text { data on } 100 \text { participants from out of area, rehabilitation and acute units. Financial data } \\
\text { was provided by the Health Board. Other data was gathered by two clinicians from } \\
\text { case records and staff interviews. } \\
\text { Findings } \\
26 \cdot 0 \% \text { of people were inappropriately placed, with frequent overprovision of support. It } \\
\text { was calculated that within an annual budget of } £ 12 \cdot 7 \mathrm{M}, £ 2 \cdot 5 \mathrm{M}(19 \cdot 7 \% \text { of the total } \\
\text { expenditure on this patient group) could be saved if all placements were appropriate. } \\
\text { Interpretation } \\
\text { There were differences between the three cohorts. Those placed out of area had the } \\
\text { most complex needs, although those in rehabilitation placements were similar. Most } \\
\text { participants had been in contact with services for more than five years. A system better } \\
\text { matched to their needs would benefit these patients and would also generate financial } \\
\text { savings for reinvestment in the mental health economy. }\end{array}$ \\
\hline
\end{tabular}


Funding

This work was funded by Public Health Wales, Bangor University and the Local Health Board. 


\section{Title}

An assessment of need for mental health rehabilitation amongst in-patients in a Welsh region

\section{Background}

Rehabilitation services have received little attention in the literature compared with other types of mental health service provision over the past 15 years. However, they are an important component of whole-system functioning in mental health services. Lack of provision has a particular impact on acute in-patient services. Poor pathway management can result in delayed discharges, placement of service users far from home, and resultant loss of resource for the local mental health economy.

\section{Methods}

A cross-sectional study gathered demographic, clinical, service utilisation, and financial data on 100 participants from out of area, rehabilitation and acute mental health units. Financial data was provided by the Health Board. Other data was gathered by two clinicians from case records and staff interviews.

\section{Findings}

$26.0 \%$ of people were inappropriately placed, with frequent overprovision of support. It was calculated that within an annual budget of $£ 12 \cdot 7 \mathrm{M}, £ 2 \cdot 5 \mathrm{M}(19 \cdot 7 \%$ of the total expenditure on this patient group) could be saved if all placements were appropriate.

\section{Interpretation}

There were differences between the three cohorts. Those placed out of area had the most complex needs, although those in rehabilitation placements were similar. Most participants had been in contact with services for more than five years. A system better matched to their needs would benefit these patients and would also generate financial savings for reinvestment in the mental health economy.

\section{Funding}

This work was funded by Public Health Wales and the Local Health Board.

\section{Conflicts of Interest}

There are no conflicts of interest. 


\section{Background}

Since the closure of large mental hospitals, in-patient rehabilitation services have received little attention from policy makers. Reliance upon the private sector to provide beds has resulted in unplanned growth in services without reference to local need.1 Current mental health strategies in England and Wales make no reference to rehabilitation services.2,3 Nonetheless, the Joint Commissioning Panel for Mental Health has given clear and helpful guidance to commissioners about the content of rehabilitation care pathways, the importance of whole system working, and the need for services to be close to service users' homes.4

Acute and secure in-patient services are only effective when there is an active care pathway for service users to leave them and where the pathway operates as a whole system.5 Sometimes this requires greater support than can be offered through standard community mental health team (CMHT) care coordination. Where local services lack clear pathways and adequate rehabilitation provision, service users are at risk of placement in out of area treatment settings (OATS), often at a distance from family and friends.6,7 Such placements are an unbudgeted expense which drains financial resource from the local mental health economy. This is a poor use of money, as there is evidence that service users experience equally good outcomes when rehabilitation services are located in their area of origin.8 OATS lead to inefficient use of staff time due to coordination of placements at a distance.9 People placed in local services move more effectively through rehabilitation care pathways than those placed out of area.10 Service users prefer to be supported close to families and friends as people placed out of area find it difficult to adjust to isolation in remote locations, and struggle to relocate back in their home area when care packages end.11

Many people in acute in-patient wards have long-term needs, often for rehabilitation. Delays whilst awaiting transfer to a rehabilitation service are common.12-15 Some rehabilitation services have difficulty in moving people to suitable services following rehabilitation intervention. 16

People move more slowly through "step down" pathways than "step up" pathways, particularly when there is concern over risk. Lengthy stays in acute inpatient beds awaiting transfer to a rehabilitation setting are counter-therapeutic and lead to increased use of out of 
area placements for acute care (OATS) due to pressure on beds within the local service system. 17

\begin{abstract}
Aim
To undertake a needs assessment for rehabilitation services of people currently using secondary care mental health services within a region of Wales, including those in OATS.
\end{abstract}

\title{
Methods
}

A cross sectional needs assessment was undertaken using a designed-for-purpose proforma to gather a range of clinical, demographic and service utilisation information (see Appendix). Financial data were obtained on a case-by-case basis from the Health Board's finance department.

The cohort participants in this work were in-patients on $1^{\text {st }}$ August 2014 in one of the following settings in the National Health Service or outside this sector:

- NHS rehabilitation in-patient bed (a facility supporting people to overcome longer term disability related to mental illness, often for two years or more)

- NHS acute in-patient bed (for people experiencing an acute mental illness) with a length of stay of $>50$ days or

- Medium Secure Unit bed (for high risk people requiring security and treatment) and identified as delayed discharge awaiting rehabilitation or

- Out of area rehabilitation inpatient placement outside the NHS (for people placed away from local services)

All services within the care pathway and all patients who met the above criteria were included in the study.

The proforma was piloted. Minor modifications were made prior to data collection. 
For service users in NHS settings, demographic, clinical and service utilisation data was gathered in situ by two experienced clinicians (a consultant psychiatrist and a clinical nurse specialist, each with over 20 year's clinical practice in a wide range of settings) who examined case notes and interviewed staff on duty at the time.

Patients in out of area placements were identified using financial payment records and cross referencing these with clinical records held by staff monitoring the placements, in order to ensure all cases were identified. Data for those in OATS placements were obtained by the clinical nurse specialist who interviewed the NHS case managers responsible for individual care coordination.

In respect of the suitability of the placement, the two clinicians made a consensus assessment based on a detailed review of the patient's clinical records, including care plan and risk assessment, and a discussion with a qualified member of the care team. A Global Assessment of Functioning (GAF) score was also agreed.18 Where the reviewers considered that patients were not appropriately placed, this judgement was discussed with the member of staff and agreement reached.

All data were gathered on paper proformas and then entered into Excel by an administrator. The Excel data entries were re-checked for accuracy by the clinical nurse specialist against the hard copy data. Financial data were added to the Excel file. The dataset was then analysed using Statistical Package for Social Sciences (SPSS) software.

Permission for the study was obtained from the Health Board Clinical Audit and Effectiveness Department who deemed it a service evaluation and that local Research Ethics Committee approval was unnecessary.

\section{Findings}

Demographic, clinical and service utilisation profiles 
A total of 100 people met the study criteria: 30 within NHS rehabilitation wards; 24 in acute wards; and 46 in out of area treatment. No service user in the Medium Secure Unit met the study criteria. As $n=100$, total figures are both the number and the percentage in all tables unless otherwise stated.

The majority were male and of white British ethnicity. Those in the rehabilitation cohort were the youngest group. The OATS group contained the greater number subject to Part III of the Mental Health Act (patients concerned with criminal proceedings or under sentence). Ninety percent of the total population were subject to Section 117 of the Mental Health Act (provision for legal entitlement to aftercare following detention in hospital) indicating previous compulsory in-patient use.

\begin{tabular}{|c|c|c|c|c|}
\hline & $\begin{array}{l}\text { Rehabilitation } \\
\text { wards } \\
(\mathbf{n}=\mathbf{3 0})\end{array}$ & $\begin{array}{l}\text { Acute wards } \\
\qquad(n=24)\end{array}$ & $\begin{array}{c}\text { OATS } \\
(n=46)\end{array}$ & $\begin{array}{c}\text { Total } \\
(n=100)\end{array}$ \\
\hline Sex (Male : Female) & $23: 7$ & $13: 11$ & $34: 12$ & $70: 30$ \\
\hline Age range (mean) & $\begin{array}{c}18-67 \\
(35 \cdot 47 \text { years })\end{array}$ & $\begin{array}{c}21-87 \\
(51 \cdot 54 \text { years })\end{array}$ & $\begin{array}{c}19-72 \\
(43 \cdot 48 \text { years })\end{array}$ & $\begin{array}{c}18-87 \\
(43 \cdot 01 \text { years })\end{array}$ \\
\hline \multicolumn{5}{|l|}{ Ethnicity } \\
\hline White British & 29 & 22 & 42 & 93 \\
\hline Other & 1 & 2 & 4 & 7 \\
\hline \multicolumn{5}{|l|}{ Mental Health Act } \\
\hline Informal & 10 & 9 & 5 & 24 \\
\hline $\mathrm{S} 2$ & 0 & 0 & 1 & 1 \\
\hline $\mathrm{S} 3$ & 15 & 14 & 19 & 48 \\
\hline Part III & 5 & 0 & 17 & 21 \\
\hline Other sections & 0 & 1 & 4 & 6 \\
\hline S117 & 29 & 17 & 44 & 90 \\
\hline
\end{tabular}

Table 1: Demographic profiles 
Table 2 sets out current clinical diagnosis which were obtained from case records and interviews with clinical staff. There were fewer people with psychosis in the acute group than the other two groups. The OATS group had more people with multiple diagnoses and personality disorder.

$\begin{array}{cccc}\text { Rehabilitation } & \text { Acute wards } & \text { OATS } & \text { Total } \\ \text { wards } & (n=24) & (n=46) & (n=100) \\ (n=30) & & & \end{array}$

Primary diagnosis

Schizophrenia

22

10

20

52

Schizo-affective disorder

\section{2}

Affective psychosis

1

Personality disorder

4

Other psychosis

0

Other

1

No diagnosis currently

Number with more than one

diagnosis

\section{Table 2: Diagnosis}

A large proportion of all three groups had significant past and current risk in a range of areas (Table 3). The OATS group had a high proportion of people with risk of harm or threats to others. A history of arson was largely confined to this group.

\begin{tabular}{lcccccc}
\hline & $\begin{array}{c}\text { Rehabilitation wards } \\
(\mathbf{n}=\mathbf{3 0})\end{array}$ & $\begin{array}{c}\text { Acute wards } \\
(\mathbf{n = 2 4 )}\end{array}$ & $\begin{array}{c}\text { OATS } \\
(\mathbf{n}=\mathbf{4 6})\end{array}$ \\
\hline Historic & Current & Historic & Current & Historic & Current \\
\hline Self-harm & 24 & 11 & 12 & 10 & 25 & 13 \\
\hline Self-neglect & 22 & 14 & 20 & 10 & 34 & 23 \\
\hline Exploitation & 14 & 18 & 12 & 5 & 26 & 18 \\
\hline
\end{tabular}




\begin{tabular}{lcccccc}
\hline Harm to others & 24 & 10 & 12 & 5 & 39 & 25 \\
\hline Victim of any abuse & 9 & 2 & 19 & 2 & 14 & 5 \\
\hline Threats to others & 18 & 7 & 15 & 10 & 38 & 26 \\
\hline Arson & 2 & 0 & 0 & 0 & 10 & 1 \\
\hline $\begin{array}{l}\text { Sexually inappropriate } \\
\text { behaviour }\end{array}$ & 4 & 1 & 2 & 1 & 1 & 1 \\
\hline
\end{tabular}

Table 3: Risk profiles (historic and current)

Staff identified higher levels of alcohol and substance misuse in the rehabilitation and OATS groups (Table 4).

\begin{tabular}{|c|c|c|c|c|}
\hline Needs & $\begin{array}{c}\text { Rehabilitation } \\
\text { wards } \\
(\mathbf{n}=\mathbf{3 0})\end{array}$ & $\begin{array}{l}\text { Acute wards } \\
\qquad(\mathrm{n}=24)\end{array}$ & $\begin{array}{c}\text { OATS } \\
(n=46)\end{array}$ & $\begin{array}{c}\text { Totals } \\
(\mathrm{n}=100)\end{array}$ \\
\hline Cannabis & $13(43 \cdot 3 \%)$ & $2(8 \cdot 3 \%)$ & $14(30 \cdot 4 \%)$ & 19 \\
\hline Cocaine & $6(20 \cdot 0 \% \%)$ & 0 & $5(10 \cdot 9 \%)$ & 11 \\
\hline Amphetamines & $7(23 \cdot 3 \%)$ & $1(4 \cdot 2 \%)$ & $9(19 \cdot 6 \%)$ & 17 \\
\hline Alcohol & $11(36 \cdot 7 \%)$ & $6(25 \cdot 0 \%)$ & $17(36 \cdot 2 \%)$ & 34 \\
\hline Other substances & $1(3 \cdot 3 \%)$ & 0 & $3(6 \cdot 5 \%)$ & 4 \\
\hline
\end{tabular}

Table 4: Drug and alcohol use

In all three groups, the majority of people had been in contact with services for a long period of time. In the rehabilitation and OATS groups over three quarters had been known to services for more than five years (Table 5).

$\begin{array}{cccc}\text { Rehabilitation } & \text { Acute wards } & \text { OATS } & \text { Totals } \\ \text { wards } & (n=24) & (n=46) & (\mathbf{n}=100) \\ (n=30) & & & \end{array}$




\begin{tabular}{lcccc}
\hline$<1$ year & 0 & $3(12 \cdot 5 \%)$ & 0 & $3(3 \cdot 0 \%)$ \\
Between 1-5 years & $7(23 \cdot 3 \%)$ & $4(16 \cdot 7 \%)$ & $7(15 \cdot 2 \%)$ & $18(18 \cdot 0 \%)$ \\
$>5$ years & $23(76 \cdot 7 \%)$ & $14(58 \cdot 3 \%)$ & $36(78 \cdot 3 \%)$ & $73(73 \cdot 0 \%)$ \\
Unknown & 0 & $3(12 \cdot 5 \%)$ & $3(6 \cdot 5 \%)$ & $3(3 \cdot 0 \%)$ \\
\hline
\end{tabular}

Table 5: Length of time known to services

The two clinicians made a consensus assessment of the appropriateness of the current placement through review of case notes and interviews with staff on duty or care coordinators. They suggested the appropriate type of placement where the current placement was inappropriate (Table 6).

\begin{tabular}{lcccc}
\hline & $\begin{array}{c}\text { Rehabilitation } \\
\text { wards } \\
(\mathbf{n = 3 0})\end{array}$ & $\begin{array}{c}\text { Acute wards } \\
(\mathbf{n}=\mathbf{2 4})\end{array}$ & $\begin{array}{c}\text { OATS } \\
(\mathbf{n}=\mathbf{4 6})\end{array}$ & $\begin{array}{c}\text { Total } \\
(\mathbf{n}=\mathbf{1 0 0})\end{array}$ \\
\hline Current placement & $25(83 \cdot 3 \%)$ & $16(66 \cdot 7 \%)$ & $33(71 \cdot 8 \%)$ & $74(74 \cdot 0 \%)$ \\
\hline Rehabilitation ward & 0 & $2(8 \cdot 4 \%)$ & 0 & $2(2 \cdot 0 \%)$ \\
\hline Care or nursing home & $2(6 \cdot 7 \%)$ & $3(12 \cdot 5 \%)$ & $7(15 \cdot 2 \%)$ & $12(12 \cdot 0 \%)$ \\
\hline $\begin{array}{l}\text { Supported } \\
\text { accommodation / }\end{array}$ & $3(10 \cdot 0 \%)$ & $2(8 \cdot 3 \%)$ & $5(10 \cdot 9 \%)$ & $10(10 \cdot 0 \%)$ \\
home support & & & & \\
\hline Non-mental health & 0 & $1(4 \cdot 2 \%)$ & $1(2 \cdot 2 \%)$ & $2(2 \cdot 0 \%)$ \\
service & & & \\
\hline
\end{tabular}

Table 6: Required placement

GAF scores were formulated for $85 \%$ of the cohort by the two clinicians, who made an assessment based on the data they collected as described above. Whilst there were differences between the groups who were deemed 'appropriately placed' and those deemed 'not appropriately placed' this was not statistically significantly (Table 7). 


\begin{tabular}{llllllc}
\hline & GAF domain & N & Min & Max & Median & $\begin{array}{c}\text { Std. } \\
\text { Deviation }\end{array}$ \\
\hline Appropriately placed & Disability & 63 & 11 & 90 & 45.00 & 14.003 \\
\cline { 2 - 7 } & Symptomatology & 63 & 10 & 85 & 31.00 & 18.874 \\
\hline $\begin{array}{l}\text { Not appropriately } \\
\text { placed }\end{array}$ & Disability & 22 & 11 & 85 & 51.00 & 20.428 \\
\cline { 2 - 7 } & Symptomatology & 22 & 5 & 88 & 45.00 & 26.730 \\
\hline
\end{tabular}

Table 7: Global Assessment of Functioning (GAF) scores by appropriateness of placement

Much of the social circumstance data was unavailable in case records and therefore is not reported here.

\section{Financial analysis}

The weekly direct cost to the NHS was determined for all cases where current placement was considered appropriate to the person's needs. Where the placement was regarded as inappropriate, the cost of an ideal placement was calculated. Costs for services were based on Personal Social Services Research Unit cost findings for 2012 with an increase of $1.5 \%$ for inflation using the Bank of England General Inflation Rate Calculator Tool (Table 8). 19, 20

\begin{tabular}{lcl}
\hline \multicolumn{1}{c}{ Type of facility } & $\begin{array}{c}\text { Weekly } \\
\text { cost (£s) }\end{array}$ & \multicolumn{1}{c}{ Comment } \\
\hline Independent hospital & $2900 \cdot 00$ & $\begin{array}{l}\text { Based on median cost to the Health Board for this type } \\
\text { of facility in August 2014 }\end{array}$ \\
\hline $\begin{array}{ll}\text { Care home with } \\
\text { nursing }\end{array}$ & $647 \cdot 59$ & $\begin{array}{l}\text { Based on costs from PRSSU study in 2012 plus } \\
\text { inflation rate of 1.5\% }\end{array}$ \\
\hline Care home & $647 \cdot 59$ & Based on costs from PRSSU study in 2012 plus \\
\hline
\end{tabular}


inflation rate of $1.5 \%$

\begin{tabular}{lll}
\hline $\begin{array}{l}\text { On site supported } \\
\text { accommodation }\end{array}$ & $248 \cdot 00$ & $\begin{array}{l}\text { Based on } £ 12 \cdot 30 \text { per hour for three people an hour } \\
\text { with } 40 \text { hours support to the group and } 7 \text { nights sleep } \\
\text { in at } £ 36 \text { per night }\end{array}$ \\
\hline $\begin{array}{l}\text { Floating support } \\
\text { package }\end{array}$ & $123 \cdot 00$ & Based on $£ 12 \cdot 30$ per hour and 10 hours a week \\
\hline
\end{tabular}

Table 8: Financial costs by facility type and rationale for establishing weekly costs

The weekly NHS expenditure for the whole sample was calculated as $£ 245,417$, which equates to an annual cost of $£ 12 \cdot 76 \mathrm{M}$ (Table 9). These weekly costs could be reduced by $£ 49,018$ if all placements were matched to service users assessed needs, reducing the annual spend to $£ 10 \cdot 22 \mathrm{M}$. Based on these figures there is a possible annual saving to local NHS services of over $£ 2 \cdot 55 \mathrm{M} ; 19 \cdot 97 \%$ of the total projected annual spend based on actual placements. The potential savings include single case contracted placements (often referred to as "spot contracts") to the value of $£ 1,703,402$. This would release funds for reinvestment whilst improving the quality of service to patients.

\begin{tabular}{lcccc}
\hline & \multicolumn{2}{c}{ Weekly cost (£s) } & \multicolumn{2}{c}{ Projected annual cost (£s) } \\
\hline & Actual & $\begin{array}{c}\text { If all were } \\
\text { ideally placed }\end{array}$ & Actual & $\begin{array}{c}\text { If all were } \\
\text { ideally placed }\end{array}$ \\
\hline Rehabilitation & 50,380 & 44,135 & $2,619,760$ & $2,295,020$ \\
\hline Acute & 58,866 & 48,849 & $3,061,032$ & $2,540,148$ \\
\hline OATS & 136,171 & 103,415 & $7,080,892$ & $5,377,580$ \\
\hline Totals & $\mathbf{2 4 5 , 4 1 7}$ & $\mathbf{1 9 6 , 3 9 9}$ & $\mathbf{1 2 , 7 6 1 , 6 8 4}$ & $\mathbf{1 0 , 2 1 2 , 7 4 8}$ \\
\hline Weekly differential (saving) & & $\mathbf{4 9 , 0 1 8}$ & & \\
\hline Annual differential (saving) & & & $\mathbf{2 , 5 4 8 , 9 3 6}$ \\
\hline
\end{tabular}

Table 9: Actual costs and costs if all were ideally placed in August $2014(\mathrm{n}=100)$ 


\section{Interpretation}

The people in the rehabilitation group were young, yet had been in contact with services for a long time, and almost all had been treated under the Mental Health Act (29 of 30). The majority of the whole cohort had a primary diagnosis of psychosis. It is known that around $10 \%$ of people with a new diagnosis of psychosis will develop complex difficulties that lead to the use of rehabilitation services. 21

Many participants had secondary diagnoses, with high rates of historical and current risk, and some drug and alcohol use, all of which reflect complex needs. The five participants in the rehabilitation group $(16.7 \%)$ in need of alternative placement were overprovided for in their current service.

The acute group had a more even gender distribution and were older that the other two groups. They had a wide range of diagnoses, but fewer secondary diagnoses. Historical and current risk profiles were lower than the other two groups, while a high proportion had been detained and were subject to legal aftercare provisions (S117; 17 of 24). Overall this group had shorter contact with mental health services than the other two groups. Only 16 of the 24 people $(67 \%)$ were placed appropriately. Almost a third required some form of step-down service (i.e. a lower level of care). The finding of a lower rate of substance misuse in this group is surprising. It may be due to lower rates of ascertainment or recording, or chance variation.

The OATS group contained the greatest proportion of Mental Health Act Part III detained patients, people with a primary diagnosis of personality disorder, people with multiple diagnoses, and people with historical and current risk of harms and threats to others. They had been known to services for a long time.

The services provided across the three cohorts are expensive. The resource was used inefficiently, with $26 \%$ of people inappropriately placed at the time of the needs assessment. There were potential financial savings of approximately $20 \%$, based on people being supported in the most appropriate service for their needs.

Despite there being no difference in 'disability' score between those 'appropriately' and 'not appropriately' placed score there was a higher mean 'symptomatology' score in those 'not 
appropriately placed'. This suggests noticeable features of illness may be a factor preventing people moving on and worthy of further exploration.

It is interesting to compare our study with the national rehabilitation services study in England.22 Both studies identified mainly male cohorts who were around 40 years of age. The majority were long term users of secondary care mental health services with previous hospital admissions. Historical self harm rates were similar between the two studies. There are some differences. The English study found almost $90 \%$ had a primary diagnosis of schizophrenia, schizo-affective disorder or affective psychosis, whereas the Welsh study identified two thirds with diagnoses of psychosis and a significant proportion of people with a primary diagnosis of personality disorder. Self neglect and harm to others were found in three quarters of the Welsh cohort, whereas these historical risks were observed in around half of the English cohort. GAF social function score had a mean of 45 , which is nine points less than in the English study. Lengths of stay were shorter in the Welsh study. An explanation for the differences may be found in inclusion of all patients in need of rehabilitation in the Welsh study, whereas the English study included only people resident in NHS rehabilitation facilities only.

Finally, there are some limitations associated with this work that should be noted. In particular, the clinical reviewers were unable to interview patients in the study. The GAF was the only standardised tool that was utilised although the data collection proforma had been used in a number of other similar settings. Staff interviews may have introduced a bias and data from casenotes may have contained some inaccuracies or missing information as they were paper based. There was a considerable amount of missing data on the social circumstances.

\section{Conclusions}

In England and Wales, the closure of mental hospitals has left a small but significant group of people with inadequate local services. They are people with complex mental health needs, and they are amongst the most vulnerable in the mental health system. Relying heavily upon the private sector to provide specialist care does not appear to be cost efficient, and there is evidence of unnecessary expenditure on inappropriate placements. 
People with long term mental health needs are not adequately served by service systems that are primarily focused upon risk, crisis, and acute care. Failure to address their needs has an impact on the availability of acute care facilities. 23 Effective acute care services require a whole system approach, including well-managed local rehabilitation pathways. Those who commission or manage services must recognise the importance of rehabilitation provision if they are to avoid wasteful and inappropriate expenditure. Inappropriate care provision is detrimental to patients. It also leads to loss of financial resource to the local mental health economy.

Remote location of facilities was one of the key problems with the asylum system. It is replicated in the modern virtual asylum. The problem persists fourteen years after the term was coined.1 Residential placements far from family and friendship networks, away from local services that should support them as they move into recovery are inappropriate and inhumane. There are major difficulties in monitoring remote placements. Overprovision of care is damaging. Patients can become demoralised and demotivated and can be regarded as incarcerated and stuck. The lack of alternative service provision, such as Early Intervention, for younger people with psychosis within the acute care pathway, prior to contact with rehabilitation services within this region, may contribute to the profile of the cohort. The present study was conducted in Wales. England has a reliance on OATS, despite persistent efforts to change this. Both countries would benefit from national studies that examine all rehabilitation services, including those outside the NHS as they are a significant part of the service system, and the need for rehabilitation where people may be stuck in other parts of the pathway, such as acute in-patient or secure services. 


\section{References}

1. Poole R, Ryan T, Pearsall A. The NHS, the private sector, and the virtual asylum. British Medical Journal. 2002; 325, 349-50. doi: http://dx.doi.org/10.1136/bmj.325.7375.1300/b

2. Her Majesty's Government and Department of Health. No health without mental health: A cross-government mental health outcomes strategy for people of all ages. HM Government / Department of Health. 2011. Available at: https://www.gov.uk/government/uploads/system/uploads/attachment_data/file/213761 /dh 124058.pdf Accessed $11^{\text {th }}$ February 2016.

3. Welsh Government. Together for Mental Health: A Strategy for Mental Health and Wellbeing in Wales. Welsh Government: Cardiff. 2012. Available at: http://gov.wales/docs/dhss/publications/121031tmhfinalen.pdf $\quad$ Accessed $\quad 11^{\text {th }}$ February 2016.

4. Joint Commissioning Panel for Mental Health. Guidance for commissioners of rehabilitation services for people with complex mental health needs. London: JCPMH. 2013. Available at: http://www.rcpsych.ac.uk/pdf/rehab\%20guide.pdf Accessed $11^{\text {th }}$ February 2016.

5. The Commission to review the provision of acute inpatient psychiatric care for adults (2015) Improving acute in-patient psychiatric care for adults in England: Interim Report. London: Royal College of Psychiatrists. Available at: http://media.wix.com/ugd/0e662e_a93c62b2ba4449f48695ed36b3cb24ab.pdf Accessed $11^{\text {th }}$ February 2016.

6. Killaspy H. The ongoing need for local services for people with complex mental health problems. Psychiatric Bulletin. 2014; 38, 257-259, doi: 10.1192/pb.bp.114.04847 
7. Ryan T, Pearsall A, Hatfield B. Long term care for serious mental illness outside the NHS: a study of out of area placements. Journal of Mental Health. 2004; 13, 425-9. doi:10.1080/09638230410001729861

8. Ryan, T, Hatfield B, Sharma I, Simpson V, McIntyre A. A census study of independent mental health sector usage across seven Strategic Health Authorities. Journal of Mental Health. 2007; 16, 243-253. doi:10.1080/09638230701279824

9. Killaspy H, Rambarran D, Harden C, Fearon D, McClinton K. A comparison of service users placed out of their local area and local rehabilitation services. Journal of Mental Health. 2009; 18, 111-120. doi:10.1080/09638230701879235

10. Hatfield B, Ryan T, Simpson V, Sharma I. (2007) Independent sector mental health care: a study of private and voluntary sector placements in seven Strategic Health Authority areas. Health and Social Care in the Community. 2007; 15: 5, 407-416. doi:10.1080/09638230701279824

11. Rambarran D. Relocating from out-of-area treatments: service users' perspective. Journal of Psychiatric and Mental Health Nursing. 2013; 20, 696-704. DOI: $10.1111 /$ jpm.12003

12. Commander M, Rooprai D. (2008) Survey of long-stay patients on acute psychiatric wards. Psychiatric Bulletin 2008; 32, 380-3. doi: 10.1192/pb.bp.107.018507

13. Holloway F, Wykes T, Petch E, Lewis-Cole K. The new long stay in an inner city service: a tale of two cohorts. International Journal of Social Psychiatry. 1999; 45, 93-103. doi: 10.1177/002076409904500202

14. Cowan C, Walker P. New long-stay patients in a psychiatric admission ward setting. Psychiatric Bulletin. 2005; 29, 452-4. doi: 10.1192/pb.29.12.452

15. Poole R, Pearsall A, Ryan T. Delayed discharges in an urban in-patient mental health service in England. Psychiatric Bulletin. 2014; 38, 66-70. doi: 10.1192/pb.bp.113.043083 
16. Cowan C, Meaden A, Commander M, Edwards T. In-patient psychiatric rehabilitation services: survey of service users in three metropolitan boroughs. The Psychiatrist. 2012; 36, 85-89. doi: 10.1192/pb.bp. 110.033365

17. National Mental Health Development Unit. In sight and in mind: a toolkit to reduce the use of out of area mental health services. London: Royal College of Psychiatrists. 2011. Available at: http://www.rcpsych.ac.uk/pdf/insightandinmind.pdf Accessed $11^{\text {th }}$ February 2016.

18. Jones S, Thornicroft G, Coffey M, Dunn G. A brief mental health outcome scale: reliability and validity of the global assessment of functioning (GAF). British Journal of Psychiatry. 1995; 166, 654-9. doi: 10.1192/bjp.166.5.654

19. Personal Social Services Research Uni. Unit Costs of Health \& Social Care. University of Kent: PSSRU. 2012. Available at: https://kar.kent.ac.uk/32408/1/fullwith-covers.pdf Accessed $11^{\text {th }}$ February 2016.

20. Bank of England Inflation Calculator Tool. Available at: http://www.bankofengland.co.uk/education/Pages/resources/inflationtools/calculator/fl ash/default.aspx Accessed $11^{\text {th }}$ February 2016.

21. Craig T, Power P, Rahaman N, Colbert S, Fornells-Ambrojo M, Dunn G. (2004). The Lambeth Early Onset (LEO) Team: Randomised controlled trial of the effectiveness of specialised care for early psychosis. British Medical Journal. 2004; 329, 1067-1071. doi: $10.1136 / \mathrm{bmj} .38246 .594873 .7 \mathrm{C}$

22. Killaspy H, Marston L, Omar R, Green N, Harrison N, Lean M, Holloway F, Craig T, Leavey G, King M. (2013) Service quality and clinical outcomes: An example from mental health rehabilitation services in England. British Journal of Psychiatry. 2013; 202, 28-34. doi:10.1192/bjp.bp.112.114421

23. Crisp N (2016) Old Problem, New Solutions: Improving Acute Psychiatric Care for Adults in England. London: Royal College of Psychiatrists. Available at: 
http://media.wix.com/ugd/0e662e_6f7ebeffbf5e45dbbefacd0f0dcffb71.pdf Accessed $11^{\text {th }}$ February 2016. 
Client ID

(project code)

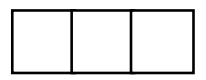

Client's postcode

(first part only)

Date of admission

Date declared

delayed

discharge (DD/MM/YY)

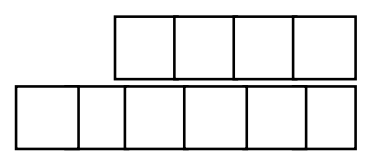

Mental health Act status

$1=$ Not subject to Act

$2=$ Section 3

$3=$ Section 2

$4=$ Other Civil MHA Section (specify)

$5=$ Part III section

Type of ward

$1=$ Acute adult admission

$2=$ PICU

$3=$ Older person's admission ward

$4=$ Rehabilitation ward

$5=$ Other (specify)

Name of service

Name of consultant

(state "No" if no consultant allocated)

Date of (last) previous admission

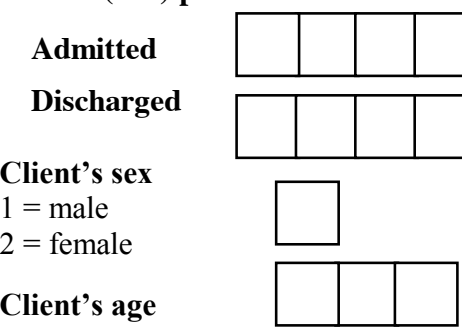

Date of birth $(\mathrm{dd} / \mathrm{mm} / \mathrm{yy})$

\section{Ethnic group}

$01=$ white British

$02=$ white other

03 = black Caribbean

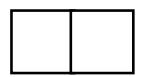

$04=$ black African

$05=$ black other

$06=$ Indian

$07=$ Pakistani

$08=$ Bangladeshi

$09=$ Chinese

$10=$ other Asian

$11=$ other (specify) $\ldots$

$12=$ not known

Primary diagnosis (current)

$01=$ schizophrenia

$02=$ schizo-affective disorder

$03=$ affective psychosis

$04=$ other psychosis

$05=$ depression (not psychotic)

$06=$ anxiety

$07=$ personality disorder

$08=$ dementia

$09=$ eating disorder

$10=$ alcohol abuse disorder

$11=$ other substance abuse disorder

$12=$ learning disability

$13=$ other (specify)

$14=$ no diagnosis currently
Secondary diagnoses (current)

Please indicate any secondary diagnoses

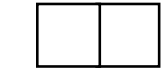

Living group

$01=$ alone

$02=$ with spouse/partner

$03=$ spouse/partner and child(ren) under 18

$04=$ child(ren) under 18 only

$05=$ child(ren) over 18

$06=$ own parents

$07=$ other family

$08=$ adults (non-family)

$09=$ other service users (non-family)

$10=$ staffed accommodation (full-time)

$11=$ staffed accommodation (part-time)

$12=$ other (specify)

$13=$ not known

\section{Housing}

$1=$ council/housing association

$2=$ owner-occupied

$3=$ rented privately

$4=$ lodgings

$5=$ homeless $/$ NFA

$6=$ NHS/SSD/voluntary/Indep provider

$7=$ Other (specify)

$8=$ not known

Informal carer

$1=$ Lives with service user

$2=$ Lives separately

$3=$ No informal carer

$4=$ Not known

Visitors whilst in hospital

1 = Daily; 2 = Weekly; $3=$ Monthly; $4=$ Less

frequently; $5=$ Never; $6=$ Don't know

Partner / wife / husband

Children

Parent

Other family

Friends

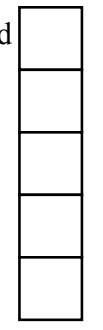

Describe any carer involvement in the MDT

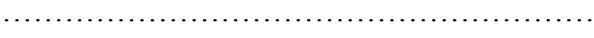

Income

$1=$ State benefits only

$2=$ State benefits $\&$ income from other sources

$3=$ no benefits received, all income from other sources

$4=$ other (specify)

$5=$ not known

\section{Employment status}

$01=$ working full-time

$02=$ working part-time

$03=$ sheltered work

$04=$ unemployed

$05=$ long-term sick

$06=$ caring for home/family

$07=$ student

$08=$ retired $09=$ working permitted hours

$10=$ other (specify)

$11=$ not known
CTP level at current time

$1=$ On CTP

$2=$ Not on CTP

$3=$ Under assessment / awaiting allocation

Does the person have the following which makes placement difficult?

$1=$ yes, $2=$ no, $3=$ not known

$1=$ Learning disability..

$2=$ Personality disorder.

$3=\mathrm{A}$ "perceived" challenging behaviour

$4=$ Other issues (specify)

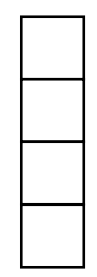

Does the person have a co-existing substance misuse problem with:

$1=$ yes, $2=$ no, $3=$ not known

$1=$ Cannabis

$2=$ Cocaine

$3=$ Amphetamines

$4=$ Alcohol

$5=$ Other substances (specify)

Are any specialist tools used to assess and / or manage? $(1$ = Yes 2 = No 3 = Don't know $)$

Learning disability

Personality disorder

Alcohol misuse

Substance misuse

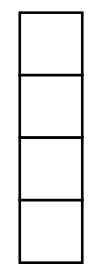

Is the person subject to S.117:

$1=$ Yes, $2=$ No, 3 = Don't know

Is the person subject to a Community

Treatment Order?

$1=$ Yes, $2=$ No, 3 = Don't know

Length of time known to mental health services

$1=$ Less than 4 weeks

$2=1-3$ months

$3=4-6$ months

$4=7-12$ months

$5=$ between 1 and 5 years

$6=$ more than 5 years

$7=$ not known

Frequency of contact with the Care

Coordinator during admission

(indicate nearest average)

$1=$ more than once per day

$2=$ daily

$3=$ less than daily, at least 3 times per week

$4=$ once per week

$5=$ once per fortnight

$6=$ once per month

$7=$ less than once per month

$8=$ less than once per 3 month

$9=$ no contact 
Local authority responsible for client (specify)

Type of contact by Care Coordinator

$1=$ Solely or mainly face to face

$2=$ Solely or mainly phone

$3=$ Roughly equal

$4=\mathrm{N} / \mathrm{A}$

How many consultant changes during the admission

How many CTP care coordinator changes during the admission

How many ward changes during the admission

Risk behaviours

1 = yes, 2 = no, 3 = not known

Self-harm

Self-neglect

Exploitation

Harm to others

Victim of any abuse

Threats to others

Arson

Other risk (specify)

Past Current

Is it appropriate for the person to be on the ward at time of review?

$1=$ Yes

$2=$ No

$3=$ Don't know (Give reason)

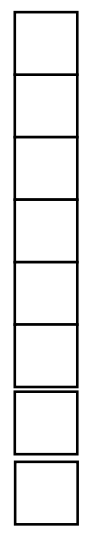

If "no", where should they be supported?

$1=$ Ward in the community

$2=$ Care home with nursing

$3=$ Care Home

$4=$ On site supported accommodation

$5=$ Floating support

$6=$ At own tenancy / home with domiciliary care

7 = At own tenancy / home with routine CMHT / AOT or EIT support

$8=$ PICU

$9=$ Acute inpatient adult ward

$10=$ Older adult in-patient wards

$11=$ Low secure unit

$12=$ Medium secure unit

$13=$ In a non-mental health bed (specify)

$14=$ Other

Is there a clear date where the person was no longer suitably placed on the ward?

$1=$ Yes

$2=$ No

$3=$ Don't know

If, so what was the date?

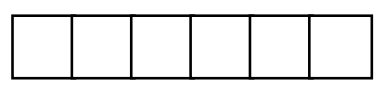

If no clear day identified indicate approximately how long

Other professionals involved during the admission (list and describe involvement)

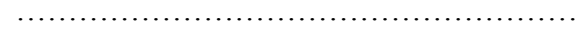

\section{Reason for delayed discharge}

$1=$ No suitable placement identified

$2=$ Placement identified but no bed available

$3=$ Care package not in place (e.g. if in own accommodation

$4=$ Other (specify)

$5=$ Not in delayed discharge

group

Type of placement required upon discharge (as identified by reviewers)

Has the type of placement been agreed by the MDT?

$1=$ Yes

$2=\mathrm{No}$

3 = Don't know (Give reason)

\section{Details of placement identified by MDT}

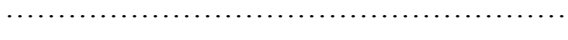

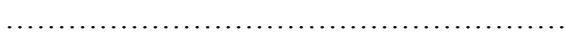

Current medication $(1=$ yes, $2=$ No)

Clozapine

Other oral anti-psychotics ....

Depot anti-psychotics

Lithium carbonate .

Other mood stabilisers

Anti-depressants

Anxiolytics

Anti-cholinesterase inhibitors

Other psychotropic medicines

Other psychiatric medications (specify)

Non-psychiatric medications

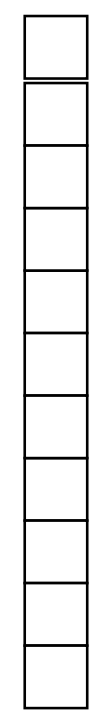

Evidence of a strategic treatment plan

$$
\begin{aligned}
& 1=\text { Yes } \\
& 2=\text { No } \\
& 3=\text { Don't know }
\end{aligned}
$$

Evidence of a discharge plan

$1=$ Yes

$2=\mathrm{No}$

$3=$ Don't know
Describe what is being done to move the person on from the service

n.m.

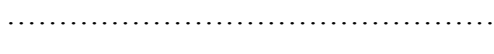

................................

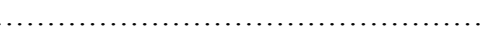

Does the person experience rapid relapse in mental health?

$1=$ Yes

$2=$ No

$3=$ Don't know

\section{Describe any intractable symptoms}

,



,

Other factors inhibiting discharge / transfer

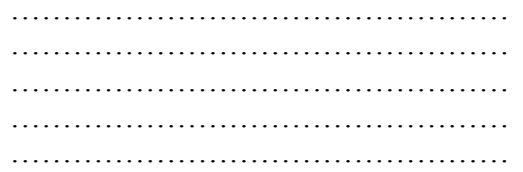

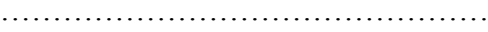

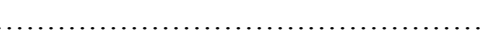

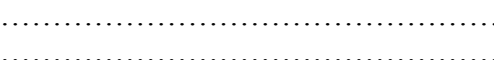

Is the care being delivered compliant with the Mental Health Measure?

$1=$ Yes

$2=\mathrm{No}$

$3=$ Partly (specify)



.

What is the person's understanding of the situation? (Do they know the staff believe they should not be on the Ward / Unit?)

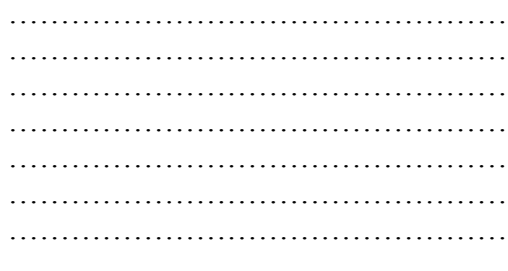

Any other comments / observations?

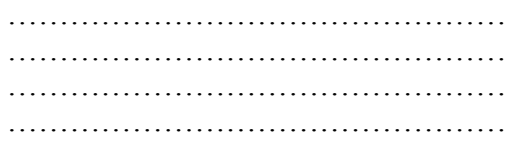




\section{Title page}

\section{Title}

An assessment of need for mental health rehabilitation amongst in-patients in a Welsh region

\section{Word length}

4,162 words including references and abstract (excludes Appendix)

\section{Authors}

Author 1: Tony Ryan, PhD (Director, Tony Ryan Associates and Honorary Research Fellow, Centre for Mental Health and Society, Bangor University) (corresponding author)

Author 2: John Carden, MSc (Clinical Nurse Specialist, Betsi Cadwaladr University Health Board and Centre for Mental Health and Society, Bangor University)

Author 3: Robert Higgo FRCPsych (Senior Lecturer, Centre for Mental Health and Society, Bangor University and Honorary Consultant Psychiatrist, Betsi Cadwaladr University Health Board)

Author 4: Rob Poole FRCPsych (Professor of Social Psychiatry, Centre for Mental Health and Society, Bangor University and Honorary Consultant Psychiatrist, Betsi Cadwaladr University Health Board)

Author 5: Catherine A. Robinson PhD (Professor of Social Policy Research, Centre for Mental Health and Society, Bangor University)

\section{Contact details for corresponding author}

Email: $\quad$ info@tonyryan.org

Mobile: 07968031087

Skype: $\quad$ tonyryan58

Address: $\quad 26$ Sergeants Lane, Whitefield, Manchester, M45 7TS 